\title{
THINKING ACROSS HEMISPHERES: FURTHER NOTES ON OVERSIGHTS AND BLIND SPOTS IN DISCIPLINARY AFRICAN STUDIES ${ }^{1}$
}

\author{
Premesh Lalu \\ Centre for Humanities Research, University of the Western Cape, South Africa
}

\begin{abstract}
In the midst of ever-hardening nationalist sentiment across the world, the humanities may need to recall its long history of thinking across hemispheres. In such balkanised times, we may have to rethink the work that a hermeneutics of suspicion performs for a critical humanities as well as how Africa is bound to particular configurations of area studies that emerge out of the geopolitical distributions of knowledge during the Cold War. To the extent that we might develop a history of a critical humanities across hemispheres, this paper asks what it might mean to return to a concept of freedom formed through a sustained effort at reckoning with the worldliness specific to the anticolonial struggles in Africa. There, a critical humanities may discover the sources of a creative work in which Africa is not merely bound to the binary of blind spots and oversights, but functions as that supplement which gives itself over to a liveable future.
\end{abstract}

KEYWORDS: COLD WAR, DEVELOPMENT, AFRICAN STUDIES, AESTHETIC EDUCATION, AREA STUDIES, CRITICAL THEORY ENLIGHTENMENT

A recent report on research collaboration between the University of the Western Cape (UWC) and Ghent University (GU) provides a commendable account of achievements across a range of research initiatives in the humanities and natural sciences. However, a brief reference to criticisms about the partnership project linking UWC and Ghent is cause for caution, in part, because it has consequences for how we think about the ways in which suspicion inaugurates aspects of the work of criticism in humanistic inquiry. The report noted that the north-south exchange was marred by the way that:

antimonian, suspicious and atomistic aspect of Freedom Struggle culture, necessary for defiance and keeping secrets in times of conflict, showed internally in a dynamic resentment of regulation from some and a tendency to pursue sectional interests rather than co-operation. Some Arts Departments were deeply suspicious of the programme and held wrongly that priorities were dictated by the donors. ${ }^{2}$

This essay builds on an earlier inquiry and lecture delivered read at the Ioth Symposium of the Ghent Africa Programme, Ghent University, 2or6. See Premesh Lalu, "Breaking the Mold of Disciplinary Area Studies," Africa Today Vol.63, no. 2, December 2016.

Stan Ridge (et.al), "The Multilingual African City in Transition: Semiotics of Negotiating Change," in Chris 
The connection between how "suspicion" of the freedom struggles of the twentieth century in Africa infiltrates academic attitudes may in fact serve a more pertinent task of realigning theoretical and critical models across hemispheres in the wake of the Cold War. By extension, and somewhat tautologically, the GU-UWC report invites us to grasp precisely how the very idea of critique must be suspected of sliding back into the sectarianism of freedom struggles in Africa. Yet, suspicion has a more complicated genealogy than Building a Better Society admits to. For example, Paul Ricouer's discernment of a hermeneutics of suspicion assigns the sources of suspicion to the critical spirit in the nineteenth century Europe. ${ }^{3}$ Largely attributed to Marx, Freud and Nietszsche, the hermeneutics of suspicion sought to unmask the lies and illusions of consciousness. Recently, Rita Felski's post-criticism has directed our attention to the proximity with which suspicion and critique operated in the Euro-American episteme, albeit with disappointingly little reflection on how colonialism figures in such relations. ${ }^{4}$ Perhaps, what is foreclosed in Felski's exposition of the endpoints of criticism is the way in which Africa, and indeed the postcolonial world more generally, is connected to a world picture only through the inaugural work of critique. While a fuller account of the relationship between suspicion and critique threaded through the colonial world is beyond the scope of this essay, the GU-UWC report nevertheless draws us toward an aspect of that relationship that belongs to the inheritance of Area Studies on which I wish to focus. In particular, a form of suspicion that underwrites the inauguration of criticism in the study of Africa is frequently faced with the uncertainty about whether such criticism should recall the blind spots or the oversights in the constitution of Africa as an object of knowledge.

In the aftermaths of colonialism and the suspicion wrought by Eurocentrism, the spirit of critique that once was a pervasive feature of nineteenth-century Europe may benefit from rephrasing. Perhaps, it is prescient to subject the growing suspicion across hemispheric divides to the same critical spirit prevalent in nineteenth century Europe. Framed as a question, we might ask how we exceed centuries old suspicions across hemispheres in the midst of a accretion of suspicion brought about by five decades of Area Studies during the Cold War? How do we plot our way out of the breakdown in the hermeneutics of suspicion in order to extend critique rather than surrendering to the suspicion from which critique draws its initial inspiration? Or more bluntly, how do we make a critical practice out of the suspicion that underwrites research relations between Africa and Europe in our times?

The actual report of the GU-UWC collaboration is not my specific concern here. Mine is an effort that attends to how the charge of suspicion that accretes in standpoints might be reoriented towards a more productive critical function in the project of knowledge across hemispheres. I am of course referring to how we are to hear the word "suspicion" that appears to mark research relations across hemispheres since the advent of slavery

Tapscott (et.al) Dynamics of Building a Better Society (Cape Town: University of the Western Cape, 20I4). 
and colonialism from the sixteenth century to the present.

At a very general level, the trope of suspicion takes two forms. The first lends itself to the problem of the blind spot in the Euro-American episteme. The second results from the justification sought in the claim about oversight. It is the combination of the two, I will suggest in what follows, that ultimately underwrites the problem of suspicion in the study of Africa. Briefly put, the blind spot refers to ways in which knowledge sometimes glosses over regional specificities and particularities, and political and social constellations, not to mention forms of subjection or its effects. In more precise Derridian terms, the blind spot calls forth a supplement by which the immediacy of natural presence is foreclosed. ${ }^{5}$ If, by extension, Africa functioned as Europe's supplement, the blind spot threathened the fulfillment of Europe's natural presence.

The blind spot however does not amount to an oversight. In the case of the oversight, the object is misrecognized; it is seen, but simultaneously not seen. Let us imagine Althusser reading over the shoulder of Marx who in turn is reading in earshot of earlier economists to help clarify the distinction. The blind spot, we might say, tallies with Marx and Althusser's criticism of earlier economists not seeing given economic facts. In other words, the blind spot refers to that which is not seen in the object as such. The oversight by contrast, is not to see what one sees; the oversight no longer concerns the object itself. For Althusser, "the oversight is an oversight that concerns vision: non-vision is therefore inside vision, it is a form of vision and hence enjoys a necessary relationship with vision." If we abide by this distinction in Marx and later, Althusser, then knowledge of Africa is a process in which it is possible not to see what one is looking at.

In reading the report on the GU - UWC exchange, I would argue that it conflates and confuses blind spot and oversight as the operative ocular mode that defined the attitude of some UWC colleagues in the broader partnership. In other words, the sense of suspicion resides in a point of irreducibility: Africa is that which prohibits Europe from arriving at the immediacy of its natural presence or viewing Africa is not seeing what one is looking at. I want to dwell on this problem, in part because I believe that turning suspicion into something that exceeds an inherited notion of a hermeneutics of suspicion in the global research community should be an effort worthy of pursuit in these balkanized and virulent nationalist times. It is critical in a moment when the fissures produced by centuries of colonialism, imperialism, capitalism and neoliberalism threaten the very worldliness of the university as institution.

Accounting for such a perceptual shift from blind spot to oversight is of course a labour that has been ongoing for decades, if not centuries. What interests me is less the shift in perspective, important as that may be, than the way the very nature of suspicion remains in tact in the midst of that shift when Africa is the object of knowledge. At the heart of what I wish to draw attention to is whether it is also possible that scholarship may be imbued with a dose of healthy suspicion, a suspicion of oversight located in vision (read

5 Jacques Derrida, Writing and Difference, Alan Bass transl. (London: Routledge, 1978).

6 Louis Althusser, Reading Capital Ben Brewster tranl. (London: New Left Books, I970) 2 I. 
Africa) rather than the blind spot located in the natural self-presencing (read Europe). In a conjuncture, when the world is undergoing a re-balkanization and a return to the premises of race war and rabid nationalism, might we discover a healthy suspicion through which we may constitute new relationships of knowledge across hemispheres. I will argue that for such a discussion to unfold, we need firstly to break out of the mould of disciplinary area studies where the question of suspicion settled in the late twentieth century. Attempts to grasp the consequences of blind spots and oversights in the Euro-American episteme have been a major concern of postcolonial theory and criticism for the past three decades. Two waves in this critique are discernable. The first relates to the proliferation of the problematic of development and underdevelopment that asks us to attend to the blind spots in the critique of imperialism, while the second invites us to tackle the oversights that inevitably result in unhealthy forms of suspicion. I propose to begin with a discussion on a postcolonial response to the geopolitics of area studies, before outlining some conditions for restoring an intellectual community across hemispheres that takes as its point of departure the Enlightenment promise of Europe and the syncretic promise of the postcolonial world.

Let us turn to the problem of area studies where suspicion became a hardened sensibility of disciplinary reason at the height of the Cold War, and where the problems of blind spots and oversights were depleted in developing new critical models for the study of Africa. At the outset of an edited volume on Intellectuals and African Development, the question is posed about what went wrong in sustaining an obvious link between knowledge and the developmental needs of a postcolonial society in the immediate aftermath of independence. ${ }^{7}$ The call for self-reflection perhaps anticipates a further question about how to account for the effects of area studies on scholarship in Africa in the era of independence and development. Much of this reflection has, of course, been occasioned by the work of scholars initially educated in African universities but who later relocated to the North American academy. Many have saliently argued about the perils of proceeding without significant and substantial overhauls to prevailing orthodoxies derived from area studies constituted in the Euro-American academy. Perhaps one way to think about the anxieties produced by area studies for scholars of African studies relates to the manner in which the consolidation of institutions of higher learning in the West after the Second World War was buoyed by knowledge from elsewhere. Dipesh Chakrabarty, in his musings on American area studies in South Asia, identifies the asymmetry between knowledge and institution as a hangover of an older connection between liberal education and empire. ${ }^{8}$ He suggests that what made these Eurocentric assumptions invisible was in part the fact that area studies were still a matter of studying foreign cultures. The question here is how a critical attitude can be harnessed from within this scene of estrangement to

Bjorn Beckman and Gbemisola Adeoti, eds., Intellectuals and African Development: Pretension and Resistance in African Politics (Dakar: CODESRIA, 2006).

8 Jackie Assayag and Veronique Benei, eds., At Home in Diaspora: South Asian Scholars and the West (Bloomington: Indiana University Press, 2003), 56. See also, Dipesh Chakrabarty, "Notes toward a Conversation Between Area Studies and Diasporic Studies," Public Culture Io (3) 1998. 
articulate another perspective on the worldliness of knowledge that the late Edward Said once encouraged. Thinking about the inheritance of area studies after Said's Orientalism (I978) or Valentine Mudimbe's Invention of Africa (I988) is what now pressures a generation towards recharging the effective history of postcolonial criticism.

If area studies produced anxiety about being in the world among scholars writing on Africa, then we might add that its consequences are considerably multiplied in the context of Africa. Rather than simply function as a receptacle of knowledge produced in the US academy, the promise of trickle-down modernity is a reason for specific attention on how best to proceed. This reflection is possible, not at the expense of the northern academy, but in relation to it, and beyond its preordained scripts of area studies formed at the height of the Cold War. It might require a reorientation, if not an overhaul of area studies, or a breaking out of its disciplinary mould and political function.

How did area studies come to be seen at the institutional site of the university in Africa, if at all? What have its been its oversights and blind spots, and what have been the consequence of such oversights and blind spots for African scholars and institutions? Rather than simply affirm the reorientation of area studies, I call attention to what it is that area studies may have foreclosed, rendering it prohibitive, rather than generative, for the academy located outside the West - what, in its oversights, may have augmented the question, "what went wrong?" and more pertinently, "what is the way out?" This is not another effort at trumping area studies in the Euro-American academies for their ideological, imperial or colonial attachments, but an effort to ask what it might mean to recast them, from the elsewhere of The Other Heading, towards institutional forms, aesthetic education, and questions of technology. Might these questions pressure thought at the limit of the geopolitics in which the modular form of area studies was first conceived? In other words, how can a review of area studies change Euro-American attitudes, rather than affirm the rising tide of racial presuppositions about the rest of the world currently taking hold in both Europe and America? If the Cold War implications of area studies are less of a concern in what I offer, it is to the extent that African studies as a specific field of area studies had made common course with the civil rights movements in the United States, and opened the face of area studies to the anticolonial nationalist and independence struggles in Africa. ${ }^{9}$ That, however, is where the energies of area studies appear to have dissipated, at least as it made common cause with a nationalist moment in the constitution of independent African states.

The consequences of area studies in Africa are difficult to gauge in any definitive sense. Several scholars point to moments of great importance, as in the cohering of intellectuals in the Centre for African Studies, initiated by Kwame Nkrumah in Ghana in the wake of independence. ${ }^{\text {Io }}$ Others point to their relative absence in the formation of intellectual

This is not to deny the contests over African studies that filtered through the African Studies Association in the I96os, and the ways in which a specifically identitarian politics functioned as an imprint on the institutional shape of African universities. 
traditions as in southern Africa. ${ }^{\mathrm{II}}$ Yet others point to their surreptitious effects in determining the questions and perspectives that define the study of Africa. ${ }^{12}$ At the very least, these questions and perspectives were themselves efforts at grasping the constraints of Cold War narratives, charged with the desire for alternative visions of the world. This is possibly the implication of the division of labor that Thandika Mkandawire and Paul Zeleza call into question in their respective works of area studies in the United States.

Beyond the criticism of the effects of area studies in the United States looms a larger question: how do we come to anticipate the form of disciplinary reason that area studies constituted for African knowledge projects and institutions? The question now comes to us forcefully, especially as the institutional mechanisms of higher education in Africa have become susceptible to a consultancy culture, which, according Mahmood Mamda$\mathrm{ni}$, truncates the academic structure towards serving the interests of development agencies. ${ }^{13}$ One possible reading of this drift towards a consultancy culture, beyond the lack of funding commitment by African states for higher education, or a capacious notion of neoliberalism, rests with the way African studies programs such as the Title VI grants in the United States generally bypassed institutional mechanisms in Africa. The consequence is that African universities were increasingly placed in competition with non-governmental organizations (NGOs) for funding resources, rather than being viewed as co-constitutors in the knowledge project. Today, many NGOs have mostly displaced the institutional site of the university as an extension of Euro-American interests. Bypassing the traumatized university, area studies programs now forget that their earlier attachments may have resulted in answering, in part, what precisely went wrong.

As a specific form of disciplinary reason, area studies, especially in the United States, tended to bypass the question of building institutions of higher learning in Africa. By disciplinary reason, I mean specifically a knowledge project set against what is both knowable and still to be known. Disciplinary reason is free of risk, holding both subject and object in place by blocking the flow of desire. Such disciplinary alignments between the "Global North" and "Global South" functioned to thwart the creative act or work required in the formation of durable institutions of knowledge in Africa. While the Rockefeller, Ford, Mellon and a few other foundations required institutional development as a basis for making grants, most North American programs originating at higher education institutions tended to bypass African institutions. African institutions were increasingly pressured to secure greater access to much needed resources through consultancies. If a longer genealogy of area studies is undertaken, we might find that its formation reaches beyond the Cold War into the age of empire, and the protocols established in the age of empire of knowing as a basis of governing.

Area studies arguably tended to see African institutions as a continuation of modular

Brian Raftopolous, “Zimbabwe Institute of Development Studies: The Early Context of Sam Moyo's Intellectual Development”, Agrarian South Journal (forthcoming).

Paul Tiyambe Zeleza, ed., The Study of Africa, Vol. 1: Disciplinary and Interdisciplinary Encounters (Dakar: CODESRIA, 2006), and The Study of Africa, Vol. 2: Global and Transnational Engagements (Dakar: CODESRIA, 2007).

Mahmood Mamdani, Scholars in the Marketplace (Dakar: CODESRIA, 2007). 
forms of disciplinary knowledge established in the West. The rise of schools in Ghana, Ibadan, Makerere, and Dar es Salaam had a direct connection to the metropolitan models of higher education. ${ }^{14}$ The rigid approach to the idea of the university inhibited experimentation with new forms of pedagogy and research. The onset of African independence was accompanied by a recharged confidence among newly formed states, resulting in a proliferation of higher education institutions across the continent. Several of these attended to the development priorities of newly independent states. Those that rose to prominence were integrally involved in a critique of the limits of independence in a political economy that proved resilient to the paradigms of African development. Area studies, it seems, remained aloof from this shift that defined institutional emergence in Africa. That was not all to which area studies appeared to be aloof. Neglect of an account of institutional form meant that the possibilities of suturing links between an aesthetic realm beyond the university were deferred. This had detrimental consequences for the project of building institutions of higher learning. It inhibited a self-styled post-independence university from drawing on aesthetic resources to break the hold of the instrumentality of colonial reason in the formation of the university in Africa. Area studies, with its geopolitical priorities, failed to appreciate the potential of an aesthetic realm to nurture a new concept of independence - one that exceeded the limits of scripts of development. A result of this unfortunate disconnect was that arts, music, film and theater education always lagged behind statist demands for a technologically overdetermined understanding of modernization. The flourish of literature, music, art, performance and film in the wake of independence seemed to be completely obscured as interventions in the making of an African modernity or political subject. Most were jettisoned to a life outside the university, where perhaps, fortuitously, the artistic practices flourished. At the institutional site of the university in Africa, the once-thriving attention to the creative disciplines in Ghana and Dakar in the I96os, for example, appear gradually to have been displaced by privileging social sciences in area studies programs in the I980s. ${ }^{15}$

The modality of area studies that defined relations between the Euro-American academy and Africa arguably resulted in a breakup of epistemic duration. This breakup gave to African independence a poetics and temporality that enabled its intellectuals to work on unraveling the event of colonialism. Area studies carved up the epistemic field, perpetuated and compelled disciplinary reason at the expense of finding a concept of the humanities that would affect the emergence of institutions of higher learning in Africa, and perhaps cut short an opportunity to debate the priorities and shortcomings of liberalism conceived in a Euro-American episteme. Rather than finding the potential for an antidisciplinary provocation in Africa that would give to the humanities its most sustainable resource, Africa was reduced to a case study, a research site, and more recently, a destination for humanitarian, development aid and study abroad. Each, in turn, has replenished the disaster that awaits the epistemic revival of African scholarship, either by acting as

I4 See Carol Sicherman, Becoming and African University (Trenton, USA: African Research and Publications, 2005).

I5 For a comparative example of the privileging of social science in area studies programs, see Tim Mitchell, "The Middle East in the Past and Future of Social Science", UCIAS Series 3 (2003): I-32. 
a gatekeeper of what is acceptable disciplinary knowledge of Africa or by evacuating the space of deep conceptual thought and aesthetic education with an empirical imperative. If nationalism failed to come into its own because it was always seemingly belated in the story of the nation, area studies seem to have nailed that sentiment to the proverbial mast of knowledge and geopolitics by thwarting desire and undoing aesthetic education.

But this script is already coming apart in the United States, where scholars today transgress disciplinary boundaries readily and freely, experiment endlessly, and shift directions effortlessly, while their African counterparts are pressured by demands for more case studies. Area studies for Africa function less as a narrative of the Cold War than as a disciplinary prescription that binds scholars on the continent to the vicissitudes of an institutional apparatus stripped of a desire for the crafting of postcolonial freedom.

The study of Africa is cast in the mold of area studies in part because we come after the geopolitics that defined the Cold War, and in relation to which the project of knowledge and of emancipation was attenuated. Any further deconstruction of what is already coming apart requires a process of learning how we are to preserve a healthy attitude towards knowledge produced in Africa. Such a perspective is now available in sections of the American academy following the significant cultural and political debates surrounding the discipline of comparative literature, itself a product of the Cold War program of area studies. ${ }^{16}$ African studies in both the United States and Africa may need to take a leaf from the book of learning to learn how to reorient its potential toward what Achille Mbembe recently called a planetary library.

If the developmentalism of area studies does not exhaust the possibilities of establishing a research community, how might we imagine a new research relation across hemispheres? The idea of a reconstituted world picture may be useful point of departure through which to conceive of the stakes in this new relationship. The call for a reconstituted world picture is not to be mistaken for a call for an inclusive library, although that would not be an entirely unreasonable expectation. To remain at the level of probing representativeness is to merely call attention to the blind spot in Euro-American discourses, and to come to terms with the impossibility of fulfilling this ambition. However, under prevailing conditions of mass migrations and the threat of the resurgence of race war, the idea of a world picture might set to work on the question posed by Bernard Stiegler in Decadence of Industrial Democracies: Can we conceive of a Europe that is not Eurocentric? ${ }^{17}$ And by extension, what aspects of Africa remains unseen that may yet enable the question of a non-Eurocentric Europe in all its permutations?

A reorientation of the question demands a shift in the terrain on which we might set to work. The first shift relates to a formation of biopolitics as a resolution to the problem of race war that transplants the category of race to the outer reaches of the colony where it festers as an open wound. This while it produces a normalized power of pastoral power in Europe, even when through colonialism, power experiments with many of the

I6 Gayatri Spivak, Death of a Discipline (New York: Columbia University Press, 2003).

I7 Bernard Stiegler, The Decadence of Industrial Democracies Daniel Ross and Suzanne Arnold transl. (London: Polity Press, 20II). 
debilitating precepts in the colonial world. The second shift relates to the tendency to separate the human from its technological potential, such that the history of technology can only ever be imagined as instrumental, and European. The rise of fascism and the critique of technological overdeterminism by scholars such as Max Horkheimer and Theordor Adorno are reminiscent of this worry with the instrumentalisation of technology, which when transported to Africa, underwrites the post-independence script of modernization. ${ }^{\mathrm{I}} \mathrm{A}$ third shift in terrain must address itself to how the long twentieth century produced a condition that in Africa emblematically set aesthetics apart from politics and education. Taken together, Africa was not only left out of the planetary library, but its repositioning in the world often rendered it a recipient of some of the worst experiments in European knowledge formations. Might this have been behind the pithy but devastating formulation echoed by Fanon when he pleads to "leave this Europe where they endlessly talk about man, yet murder men everywhere they find them." 19

Unsurprisingly, this concern with an inheritance of knowledge in Europe, folded into the geopolitics of the Cold War and its excessive conditions of war and technological overdetermination, is now symptomatically expressed in the desire and demand for a decolonisation of knowledge. Two cautions need highlighting. First, the demand for decolonisation, especially in South Africa, seems increasingly to veer towards the problem of the blind spot, of the texts that have been omitted from curricula, and of the larger Pan African debates that have shaped resistance to a colonial inheritance and nationalist shortcomings in addressing this colonial inheritance. Two, there is a demand for a change of the institutional form of the university in Africa. Both may be mistaken for seeking a supplement to the natural presence of a master signifier. The intensification of student struggles in South Africa appears to reflect a demand for a corrective to the dispensation of the university. Unlike earlier programmes of decolonisation in immediate aftermath of independence elsewhere in Africa, the current demand for decolonisation in South African runs two discrepant propositions together: on the one hand there is a demand for content transformation, while on the other a demand for a change in the form of the academy.

The conflation is producing a condition of impasse in which the opportunity to enable the content to exceed the form is jettisoned. In other words, one can only rework the institutional space of the university if its content exceeds its form. To run content and form together is to evacuate the scene of aesthetics and style that are fundamental to the question of knowledge and its performance. The result of conflating content and form in an argument about decolonisation ignores the perils of the pitfall of nationalism that Fanon once warned about when he argued that you can never make colonialism blush for shame by spreading out little-known cultural treasures under its eyes. ${ }^{20}$

As a symptom, the conflation is specifically decipherable when one considers that the

I8 Theodore Adorno and Max Horkheimer, Dialectic of Enlightenment Edmund Jephcott transl. (Stanford: Stanford University Press, 2002).

I9 Frantz Fanon, The Wretched of the Earth Constance Farrington transl. (New York: Grove Weidenfeld, I963).

20 Fanon, I79-80. 
subject of the postcolony has been kept in its place, as a subject indelibly marked by its disindividuation, making the routes of exit and escape increasingly precarious and difficult to imagine and enact. Rather than avoiding the pitfalls of nationalism, we seem to have been dropped into the pit latrine of history. If this comes across as extreme, think only of the way human waste has denoted the signature texture of the protests amongst students in South Africa who recently dumped human excrement on the statue of Cecil John Rhodes. At the same time, the symbolic and structural conditions of an inherited past will not deliver us from the aporia in which the postcolonial subject appears to be trapped.

We need another pathway, another escape route, but one that will give to Europe an escape from the inheritance of Eurocentrism as it will give to Africa its place in a planetary library. As presumptuous as that may sound to the European ear, the sentiment is not specifically original. Recall here that very provocative passage from Derrida's The Other Heading:

'But beyond our [Europe's] heading, it is necessary to recall ourselves not only to the other heading, but especially to the heading of the other, but also perhaps to the other of the heading, that is to say, to a relation of identity with the other that no longer obeys the form, the sign, or the logic of the heading, nor even of the antiheading - of beheading and decapitation.'21

I am drawn to this formulation in part because it recalls the syncretic nature of the world that generations of postcolonial theorists have struggled to come to terms with, despite colonial difference. Whether in the Marxism of CLR James who once asked us to think of ourselves in the West but not of the West, or Edward Said who asked us to contemplate the world from the exilic position of a specular border intellectual, we have precedents to pursue the desire for The Other Heading. It is a sentiment that Lisa Lowe recently articulated in her Intimacy of Four Continents, especially as she retraces the features of globalization in the growing interconnectedness of the world across discordant encounters with modernity. $^{22}$

But I am also drawn to the excerpt from Derrida because of a shared interest in the theme of decapitation, not least as we both hear in that script the pithy Foucauldian injunction that we have still to cut off the Kings head. ${ }^{23}$ What Foucault means here is that the shift from power as property to power as effect remains incomplete, or that the content of power does not exceed the form of the sovereign power. Stated differently, we might deduce from the metaphor of the king's head the problem that beset the exercise of power in which the revolution of the nineteenth century remained incomplete. Beyond that demand for decapitation, of rendering power as effect rather than as property of the

Jacques Derrida, The Other Heading: Reflections on Today's Europe Pascal-Anne Bault and Michael B. Naas transl. (Bloomington: Indiana University Press, 1992) 15. 
sovereign, the spectre of incomplete revolutions haunt both Europe and Africa. Amidst the ruins of the quest for revolution the question of the attitude towards the dead bedevils the very productivity of thought.

Writing in the I840s at the time of the Eighteenth Brumaire, Marx would demand this new attitude towards the dead. He writes in the midst of the turmoil of the Eighteenth Brumaire,

'The social revolution of the nineteenth century cannot draw its poetry from the past, but only from the future. It cannot begin with itself before it has stripped off all superstition in regard to the past. Earlier revolutions required recollections of past world history in order to drug themselves concerning their own content. In order to arrive at its own content the revolution of the nineteenth century must let the dead bury the dead. There the phrase went beyond the content; here the content goes beyond the phrase. ${ }^{24}$

Marx was determined to show that the modern revolution would seek its inspiration by way of its own content. In fact, it would have to define the very content upon which the revolution would come to rest. But Europe in the I93os reawakened the dead with the rise of fascism, leaving in their wake a landscape littered with and haunted by mangled bodies. In a technologically overdetermined moment, Europe would discover the content did not really surpass the phrase, and that the angel of history would have to look upon the ruins with its back towards the future, rather than simply derive inspiration from the poetry of the future. In a world marked by despair and pending catastrophe, Benjamin would revisit the philosophy of history as a discourse that would be with us into the future. The moment between the great wars would leave a scar on the European landscape and psyche, and alongside it, the entire world would be beholden to the spectre not of revolution, but death. Beheading and decapitation will prove inadequate metaphors for the shape of modern power. Sovereign power was dangled before the Whig concept of history and progress and in spectacular fashion, a mode of biopower with its pastoral overtures and proprietary rights to power couched in overly nationalist sentiment became the order of the day. In Africa we have come to know this story of an incomplete revolution as one of a bifurcated state and bifurcated political subject, torn between the indecisions about citizenship and subjecthood. And lest we forget, the resolution that was sought for Europe was often worked out in experiments conducted in the far reaches of empire, which for all intents and purposes, became a laboratory for modernity.

It was this irresolution, or to use a word that would be preferable, the aporia that Derrida sort to gesture towards in The Other Heading. And what if this Europe, the Europe that was not the one that Fanon asks us to forget, were this, Derrida asks:

'The opening onto history for which the changing of the heading, the relation to the other heading or to the other of the heading, is experienced as always possible? An opening and a non-exclusion for which Europe would in some way be responsible? 
For which Europe would be, in a constitutive way, this very responsibility? As if the very concept of responsibility were responsible, right up to its emancipation, for a European birth certificate?'25

It is to this gesture, rather than an attitude to the dead, that postcolonial theorists were directing us. To use Gayatri Spivak's formulation the critique of postcolonial reason amounted to an effort to $a b$-use the enlightenment, to learn to use it from below. ${ }^{26}$ Postcolonialism was not an effort to delink from Europe, but to realize Europe's failure to grasp the content of its revolution that it may exceed the phrase. Postcolonialism functioned less as a strategy of difference than as a supplement to and trace of Europe's incomplete modernity and concept of revolution.

But the beheading of the king is not a story of Europe's alone. Some years ago, I was taken up with the case of the alleged beheading of a Xhosa king and the efforts of a healer diviner to retrieve the skull of the king at the height of the Truth and Reconciliation Commission. ${ }^{27}$ In this moment when history could neither provide the evidence nor the narrative for reconciling past and present, let alone Europe and Africa, the story of the killing of Hintsa in 1834 , at the time of the aborigines commission in Britain and the end of the Atlantic Slave Trade invited us to consider what it meant to write a history after apartheid. Rather than call for an alternative history, the Deaths of Hintsa asks what it might mean to stay with the problem bequeathed from the nineteenth century, but to do so in a way that rearranges the terms colonialism, apartheid and post-apartheid and postcolonial freedom, so that we might find a way to attend to the thought of that which remained incomplete in the very revolutions of the nineteenth century. Between the prospect of living with the dead and thinking ahead, I drew inspiration from another pithy statement, this time by Roland Barthes in his study of Michelet. Barthes writes, citing Michelet, that "history always teaches how we die, never how we live." ${ }^{28}$ Perhaps, death lies in the persistence of suspicion, which when the product of oversights and blind spots, gives us the intrigue of the Cold War rather than the poetry of the future. In pursuing new relations of research across hemispheres, we may need to rearticulate not only what is absent from our discourse, but rather the latent content that remains stubbornly unseen in what we see. The name of that gesture is postcolonialism, and the condition for it is a practice of postapartheid freedom. But that I shall leave as a story for another time and The Other Heading.

\footnotetext{
25 Derrida, The Other Heading 30.

26 Gayatri Chakravorty Spivak, An Aesthetic Education in the Era of Globalisation (Cambridge: Harvard University Press, 2013).

27 Premesh Lalu, The Deaths of Hintsa: Postapartheid South Africa and the Shapes of Recurring Pasts (Cape Town: HSRC Press, 2009).

28 Roland Barthes, Michelet Richard Howard transl. (Berkeley: University of California Press, I987) I04.
} 